\title{
PERTUMBUHAN KAMBING PERANAKAN ETTAWA PADA PEMBERIAN DAUN LAMTORO DAN DAUN MANGGROVE DENGAN KOMBINASI YANG BERBEDA
}

\author{
La Ode Sahaba ${ }^{1}$, HarapinHafid ${ }^{2}$, AmrullahPagala ${ }^{2}$ \\ ${ }^{1}$ Alumnus Program Studi Magister Peternakan Universitas Halu Oleo \\ ${ }^{2}$ Dosen Tetap Fakultas Peternakan Universitas Halu Oleo, Kendari \\ Email: sahaba12345@yahoo.co.id
}

\begin{abstract}
ABSTRAK
Penelitian ini bertujuan untuk: (1) mengkaji pertumbuhan kambing peranakan ettawa, dan (2) Mengkaji komposisi karkas kambing peranakan ettawa. Materi penelitian ini menggunakan 12 ekor kambing peranakan Ettawa jantan dengan kisaran umur 6 bulan sampai 11 bulan serta dibagi menjadi 12 petakan kandang individu. Bahan yang digunakan terdiri dari pakan (dan daun bakau), air, garam, dan obat-obatan.

Hasil penelitian menunjukkan bahwa: (1) Pemberianpakan bakau dan pakan campuran (lamtoro + bakau) belum mampu meningkatkan tingkat konsumsi pakan, pertambahan bobot badan dan konversi pakan. (2) Pemberianpakan yang berbeda tidak memberikan pengaruh yang nyata pada bobot potong, bobot karkas, dan persentase karkas. Sedangkan pada bobot potongan karkas, hanya bobot rusuk (rack) yang menunjukan perbedaan yang nyata. (3) Pemberian pakan yang terbaik diperoleh pada perlakuan P4 (lantoro $75 \%$ + bakau 25\%). Olehnya itu, perlu dilakukan penelitian lebih lanjut mengenai pertumbuhan dan produksi karkas kambing peranakan etawa dengan pemberian berbegai jenis hijauan makanan ternak dengan penambahan pakan tambahan atau pakan komersial sehingga dapat meningkatkan pertambahan bobot badan dan bobot karkas kambing peranakan ettawa.
\end{abstract}

Kata kunci: Pertumbuhan, kambing ettawa, pertambahan bobot, karkas, pengaruhnyata.

\begin{abstract}
This study aims to: (1) assess the growth of ettawa peranakan goats, and (2) to examine the composition of ettawa goat carcass. This research material used 12 male goats peranakan Ettawa with age range 6 months to 11 months and divided into 12 individual cage plot. The materials used consist of feed ( and Leaf Mangrove), water, salt, and medicines.

The results showed that: (1) Feeding of mangrove and mixed feed (lantoro + mangrove) has not been able to increase the level of feed consumption, body weight gain and feed conversion. (2) Different feeding has no significant effect on cutting weight, carcass weight, and carcass percentage. While on the weight of carcass pieces, only the weight of ribs (rack) which shows the real difference. (3) The best feeding was obtained at treatment P4 (lantoro $75 \%$ + mangrove 25\%). Therefore, it is necessary to conduct further research on growth and production of etawa goat carcasses by giving various types of forage with the addition of additional feed or commercial feed so as to increase the increase of body weight and carcass weight of goat peranakan etawa
\end{abstract}

Keywords: Growth, Ettawa goat, weight gain, carcass, real effect

\section{PENDAHULUAN}

Ternak kambing merupakan ruminansia kecil yang salah satu komoditas peternakan penghasil daging yang dibutuhkan oleh masyarakat. Ditinjau dari aspek pengembangannya ternak kambing sangat potensial bila diusahakan secara komersial, hal ini disebabkan ternak kambing memiliki beberapa kelebihan dan potensi ekonomi antara lain tubuhnya relatif kecil, cepat mencapai dewasa kelamin, pemeliharaannya relatif mudah, tidak membutuhkan lahan yang luas, investasi modal usaha relatif kecil, mudah dipasarkan sehingga modal usaha cepat berputar. Selain itu ternak kambing juga memiliki kelebihan lain yaitu: reproduksinya efisien karena 
dapat beranak tiga kali dalam dua tahun, memiliki daya adaptasi yang tinggi terhadap lingkungan, tahan terhadap panas dan beberapa penyakit serta prospek pemasaran yang baik. Ternak kambing memiliki peluang yang tinggi sebagai komoditas ekspor, terutama ke Timur Tengah, sampai saat ini Indonesia belum mampu mengisi peluang ekspor kambing secara kontinyu sebab populasinya yang masih sedikit, dan umumnya sebagian besar wilayah di Indonesia pemeliharaan dan pemasaran kambing masih ditujukan untuk memenuhi kebutuhan daging kambing dalam negeri, termasuk Sulawesi Tenggara.

Sulawesi Tenggara dikenal sebagai daerah bermusim kemarau panjang dengan curah hujan yang rendah yaitu kurang dari $2000 \mathrm{~mm} /$ tahun (BMG Sulawesi Tenggara, 2011). Pada musim kemarau, keadaan ini memberikantekananterhadapkehidupan ternak ruminansia yang digembalakan. Pada musim hujan ternak ruminansia tumbuh dengan baik hanya mengandalkan hijauan yang ada, namun pada musim kemarau pertambahan bobot badannya menjadi berkurang dikarenakan terbatasnya pakan yang tersedia. Kandungan protein hijauan di Sulawesi Tenggara dapat menurun sampai kurang dari 5\%, sementara kandungan serat kasarnya meningkat sehingga tidak memenuhi kebutuhan basal walaupun cukup tersedia (Darwis, 2000).

Usaha perbaikan ke arah peningkatan kualitas pakan yang diberikan harus ditingkatkan untuk meningkatkan produksi ternak kambing yang optimal. Oleh karenanya, perlu diupayakan penyediaan dan pemberian pakan yang dapat memenuhi kebutuhannya dan memiliki kualitas gizi yang memadai. Hal tersebut dapat diupayakan melalui penganekaragaman pakan sehingga terjadi saling menutupi kekurangan zat-zat pakan yang terkandung antara bahan pakan, termasuk pemanfaatan pakan melalui tanaman yang melimpah yang terdapat di sekitar lokasi usaha peternakan. Salah satu tanaman yang cukup melimpah di sSulawesi Tenggara adalah tanaman lamtoro dan tanaman manggrove. Tanaman ini cukup disukai oleh ternaka kambing, dan kandungan nutrisinya diduga kuat memberi kontribusi terhadap produktivitas ternak kambing. .

Produktivitas kambing dapat diukur melalui pertambahan bobot badan dan persentase karkas yang dihasilkan (Hafid et al., 2003; Hafid, 2011). Sementara produktivitas tersebut tidak terlepas dari penampilan produksi ternak yang dipengaruhi oleh beberapa faktor, antara lain faktor keturunan (genetik) dan faktor lingkungan yang terdiri dari pakan, pengelolaan, perkandangan, dan pencegahan penyakit (Hafid et al., 2014).

Jumlah yang rendah tidak akan mampu memberikan pertambahan bobot badan dan pertumbuhan karkas secara optimal sesuai dengan potensi genetik yang ada pada masing-masing ternak seperti kecepatan tumbuh, persentase karkas yang tinggi, hanya mungkin dapat terealisasi apabila ternak tersebut dapat memperoleh makanan yang cukup (Elvan et al., 2016).

Faktor jenis kelamin sangat berpengaruh terhadap performa produksi ternak yang disebabkan oleh adanya pengaruh terhadap jaringan tubuh sekaligus mempengaruhi pertumbuhan maupun persentase karkas ternak serta jenis kelamin menyebabkan perbedaan laju pertumbuhan pada jenis kelamin, selanjutnya pada umur yang sama ternak jantan biasanya tumbuh lebih cepat dibandingkan ternak betina. Hal ini menyebabkan bobot hidup ternak jantan lebih berat dibandingkan bobot hidup ternak betina (Hafid, 2002). Fenomena biologis ini juga terjadi pada ternak kambing peranakan ettawa (Suparman et al., 2016 ${ }^{\text {a }}$;2016 ${ }^{\text {b). }}$

Berdasarkan uraian tersebut diatas maka akan dilakukan penelitian tentang Kajian Pertumbuhan dan Komposisi Karkas Kambing Peranakan Ettawa Pada Pemberian Daun Lamtoro dan Daun Manggrove dengan Kombinasi yang Berbeda

\section{MATERI DAN METODE}

Penelitian ini dilaksanakan selama pada Bulan Maret sampai Mei 2018, yang 
bertempat di kandang milik Kelurahan Andonuhu Kecamatan Poasia Kota Kendari. Materi penelitian ini menggunakan 12 ekor kambing peranakan Ettawa jantan dengan kisaran umur 6 bulan sampai 11 bulan serta dibagi menjadi 12 petakan kandang individu Bahan yang digunakan terdiri dari pakan (dan daun bakau), air, garam, dan obatobatan.

Rancangan percobaan yang digunakan dalam penelitian ini adalah Rancangan Acak Kelompok (RAK) dengan Asumsi perlakuan pakan alami (PA) terdiri atas 3 perlakuan yaitu: PA-1 daun $100 \%$, PA-2 daun lamtoro 50\%,manggrove $50 \%$ dan PA-3 daun bakau $100 \%$ dan daun lamtoro $75 \%$ dan daun manggrove 25\%.Adapun model matematika dalam rancangan penelitian ini adalah sebagai berikut :

$$
Y \mathbf{i j}=\mu+\mathbf{i}+\varepsilon_{i j}
$$

Dimana :

$$
\begin{aligned}
& \text { Yij = } \text { Nilai pengamatan jenis } \\
& \text { pakan taraf ke-i dan } \\
& \text { ulangan ke-j. } \\
& \mu= \text { Nilai rataan umum. } \\
& \mu \mathrm{i}= \text { Pengaruh jenis pakan ke-i. } \\
& \mathrm{ij}= \text { Pengaruh galat pada jenis } \\
& \text { pakan taraf ke-i dan } \\
& \text { ulangan ke-j. } \\
& \text { mengetahui pengaruh }
\end{aligned}
$$
perlakuan terhadap peubah yang di ukur, maka data yang di peroleh di analisis menggunakan analisis ragam (ANOVA) dan jika berpengaruh nyata, maka dilanjutkan dengan Uji Jarak Berganda Duncan (Steel dan Torrie 1993).Sementara itu, parameter penelitian terdiri dari peubah pakan (konsumsi pakan dan konversi pakan dan peubah karkas (bobot badan (bobot awal, bobot akhir/potong).

\section{HASIL DAN PEMBAHASAN}

\section{Pertumbuhan Kambing Peranakan Ettawa Jantan}

Pertumbuhan merupakan indikator untuk menilai keberhasilan usaha budidaya ternak. Menurut Hafid (2005) pertumbuhan adalah pertambahan massa atau berat badan ternak perunit waktu atau dari waktu kewaktu. Pertumbuhan ternak direfleksikan oleh kunsumsi bahan kering pakan, pertambahan bobot badan harian dan konversi pakan.

\section{Konsumsi Bahan Kering Pakan}

Konsumsi bahan kering (BK) kambing PE jantan yang diberi pakan yang berbeda disajikan pada Tabel 1 .

\begin{tabular}{ccc}
\hline \multirow{2}{*}{ Perlakuan } & \multicolumn{2}{c}{ Konsumsi BK } \\
\cline { 2 - 3 } & Total Konsumsi $(\mathrm{g})$ & $\begin{array}{c}\text { KonsumsiHarian } \\
(\mathrm{g} / 60 \text { hari })\end{array}$ \\
\hline P1 & $24.890,88 \pm 1.450,37$ & $444,48 \pm 25,899^{\mathrm{a}}$ \\
P2 & $32.247,1 \pm 1.857,42$ & $575,84 \pm 33,168^{\mathrm{b}}$ \\
P3 & $31.826,51 \pm 1.939,68$ & $568,33 \pm 34,637^{\mathrm{b}}$ \\
P4 & $34.031,51 \pm 3.655,45$ & $607,71 \pm 65,276^{\mathrm{b}}$ \\
\hline
\end{tabular}

Keterangan: Angka yang diikuti superskrip yang berbeda pada kolom yang sama menunjukkan perbedaan sangatnyata $(\mathrm{P}<0,01)$

Berdasarkan data Tabel1 Pemberian pakan yang berbeda pada kambing Peranakan Ettawa (PE), menunjukkan adanya pengaruh nyata $(\mathrm{P}<0,05)$ terhadap konsumsi bahan kering (BK). Rataan konsumsi BK terendah diperoleh pada perlakuan P1 ( $100 \%$ ) yakni sebesar 444,48 $\mathrm{g} / \mathrm{hr}$ dan tertinggi pada perlakuan $\mathrm{P} 4(75 \%+$ bakau 25\%) yakni sebesar 607,71 g/hr. Rataan konsumsi BK pada penelitian ini lebih tinggi jika dibandingkan dengan penelitian Suparman et. al. (2016) bahwa rataan konsumsi BK kambing PE berkisar antara 246,91 gr/hr - 294,91 gr/hr. Namun, rataan konsumsi $\mathrm{BK}$ kambing $\mathrm{PE}$ dalam penelitian ini tidak jauh berbeda dengan penelitian Widaningsih (2012) bahwa rataan konsumsi BK kambing PE jantan muda berkisar antara 435,59 gr/hr- 473,87 gr/hr.Hasil uji lanjut menunjukkan bahwa rataan konsumsi $\mathrm{BK}$ pada $\mathrm{P} 1$ menunjukan perbedaan nyata $(\mathrm{P}<0,05)$ dengan perlakuan P2, P3 (bakau 100\%), dan P4 (lantoro 75\% + bakau 25\%). Sedangkan antara perlakuan P2, P3, dan P4 tidak menunjukan perbedaan nyata $(\mathrm{P}>0,05)$. 
Pertambahan Bobot Badan Harian

Pertambahan bobot badan (PBB) merupakan salah satu parameter yang dapat mengukur laju pertumbuhan pada ternak.
Rataan bobot badan awal, bobot badan akhir, dan pertambahan bobot badan kambing PE jantan dengan pemberian pakan yang berbeda disajikan pada Tabel 2

Tabel2. Bobot Awal, BobotAkhir, dan Pertambahan Bobot Badan Kambing PE Jantan pada Pemberian Pakan yang Berbeda

\begin{tabular}{ccccc}
\hline Perlakuan & $\begin{array}{c}\text { Bobot Badan } \\
\text { Awal (kg) }\end{array}$ & $\begin{array}{c}\text { Bobot Badan } \\
\text { Akhir (kg) }\end{array}$ & $\begin{array}{c}\text { PBB Total } \\
(\mathrm{kg})\end{array}$ & $\begin{array}{c}\text { PBB Harian }(\mathrm{g} / 60 \\
\text { hari })\end{array}$ \\
\hline P1 & $9,17 \pm 0,764$ & $14,53 \pm 0,92$ & $5,37 \pm 0,32$ & $95,83 \pm 5,74$ \\
P2 & $10,9 \pm 0,361$ & $19,27 \pm 3,00$ & $8,37 \pm 3,35$ & $149,40 \pm 59,877$ \\
P3 & $10,8 \pm 0,721$ & $18,43 \pm 1,66$ & $7,63 \pm 1,67$ & $136,31 \pm 29,898$ \\
P4 & $10,47 \pm 0,808$ & $19,43 \pm 2,94$ & $8,97 \pm 3,34$ & $160,12 \pm 59,61$ \\
\hline
\end{tabular}

Berdasarkan hasil analisis ragam menunjukkan bahwa perlakuan jenis pakan yang berbeda tidak berpengaruh nyata $(\mathrm{P}>0,05)$ terhadap pertambahan bobot badan (PBB). Rataan PBB secara statistic tidak menunjukan perbedaan yang nyata, namun dari nilai rata-rata $\mathrm{PBB}$ menunjukan bahwa P4 dan P2 cenderung memiliki PBB lebih tinggi dibandingkan dengan perlakuan P1 dan P3. Perbedaan tersebut diduga karena
PBB sangat ditentukan oleh tingkat konsumsi BK yang berbeda.

\section{Konversi Pakan}

Konversi pakan menunjukan efisiensi penggunaan pakan untuk menghasilkandaging. Rataan konversi pakan kambing PE jantan yang diberikan pakan yang berbedadisajikan pada Tabel 3 .

Tabel 3. Konversi PakanKambing PE Jantan pada PemberianPakan yang Berbeda

\begin{tabular}{cccc}
\hline Perlakuan & $\begin{array}{c}\text { Konsumsi Bahan Kering } \\
(\mathrm{g} / 60 \text { hari })\end{array}$ & PBB $(\mathrm{g} / 60$ hari $)$ & KonversiPakan \\
& $444,48 \pm 25,899$ & $95,83 \pm 5,74$ & $4,65 \pm 0,305$ \\
P1 & $575,84 \pm 33,168$ & $149,40 \pm 59,877$ & $4,26 \pm 1,548$ \\
P2 & $568,33 \pm 34,637$ & $136,31 \pm 29,898$ & $4,28 \pm 0,788$ \\
P3 & $607,71 \pm 65,276$ & $160,12 \pm 59,61$ & $4,02 \pm 0,917$ \\
P4 & & & \\
\hline
\end{tabular}

Berdasarkan hasil analisis ragam, pemberian pakan yang berbeda tidak berpengaruh nyata $(\mathrm{P}>0,05)$ terhadap konversi pakan kambing PE. Rata-rata konversi pakan berkisar antara 40,22-46,45 gr/hr yang artinya butuh pakan sekitar 40,22 gr sampai 46,45 gr pakan untuk menaikkan 1 gr bobot badan perhari. Hal ini menunjukkan bahwa penggunaan pakan tersebut kurang efisien bila dibandingkan dengan pendapat Ginting (2004) yang menyebutkan bahwa konversi pakan pada domba atau kambing adalah 6,38-8,02 . 


\section{Pemotongan dan Produksi Karkas Kambing PE Jantan}

Rataan bobot badan, bobot karkas, dan persentase karkas kambing PE yang diberi pakan berbeda disajikan pada Tabel 4

Tabel 4 Rata-rata Bobot Badan, Bobot Karkas dan Persentase Karkas Kambing PE Jantan yang Diberi Pakan Berbeda

\begin{tabular}{cclc}
\hline Perlakuan & $\begin{array}{c}\text { BobotPotong } \\
(\mathrm{g})\end{array}$ & \multicolumn{1}{c}{$\begin{array}{c}\text { BobotKarkas } \\
(\mathrm{g})\end{array}$} & $\begin{array}{c}\text { PersentaseKarkas } \\
(\%)\end{array}$ \\
\hline P1 & $14.800 \pm 1131,37$ & $5.933,00 \pm 9,90$ & $40,20 \pm 3,010$ \\
P2 & $17.750 \pm 2050,60$ & $7.319,50 \pm 985,00$ & $41,19 \pm 0,79$ \\
P3 & $18.350 \pm 2333,50$ & $8.452,00 \pm 1.295,40$ & $45,98 \pm 1,21$ \\
\hline
\end{tabular}

\section{Bobot Potong}

Berdasarkan hasil analisis ragam maka diperoleh hasil bahwa produksi karkas kambing Peranakan Ettawa jantan yang diberi pakan berbeda tidak menunjukkan pengaruh yang nyata $(\mathrm{P}>0,05)$ terhadap bobot potong, bobot karkas dan persentase karkas kambing peranakan Ettawa jantan. Hasil analisis ragam menunjukan bahwa perlakuan dengan jenis pakan yang berbeda tidak berpengaruh nyata $(\mathrm{P}>0,05)$ terhadap bobot potong kambing peranakan etawa.

\section{Bobot Karkas}

Berdasarkan hasil analisis ragam tidak menunjukan pengaruh yang nyata $(\mathrm{P}>0,05)$, namun dari rataannya tampak bahwa ada kecenderungan yang berbeda dari rata-rata bobot karkas masing-masing perlakuan. Pertumbuhan karkas sangat nyata berhubungan dengan bobot potong. Bobot tubuh yang meningkat diakibatkan oleh bobot karkas yang juga mengalami peningkatan. Hal ini sesuai dengan Rianto et. al. (2006) yang menjelaskan bahwa deposisi protein tubuh yang tinggi akan digunakan tubuh untuk pertumbuhan daging sehingga akan meningkatkan bobot karkas dan pada akhirnya meningkatkan bobot daging.

\section{KESIMPULAN}

Berdasarkan hasil dan pembahasan dapat ditarik kesimpulan sebagai berikut :

1. Pemberian pakan manggrove dan pakan campuran (lamtoro + manggrove) belum mampu meningkatkan tingkat konsumsi pakan, pertambahan bobot badan dan konversi pakan.

2. Pemberian pakan yang berbeda tidak memberikan pengaruh yang nyata pada bobot potong, bobot karkas, dan persentase karkas. Sedangkan pada bobot potongan karkas, hanya bobot rusuk (rack) yang menunjukan perbedaan yang nyata.

3. Pemberian pakan campuran (lamtoro + manggrove) termasuk pakan hijauan yang bernilai gizi tinggi baik sebagai pakan tunggual maupun sebagai pakan campuran akan tetapi belum memberikan pengaruh yang nyata terhadap bobot potong, bobot karkas, dan persentase karkas.

4. Pemberian pakan yang terbaik diperoleh pada perlakuan P4 (lamtoro $75 \%+$ manggrove $25 \%$ ).

\section{DAFTAR PUSTAKA}

Darwis, A. 2000. Seratyang tidak tercerna sebagai pembatas konsumsi bahan kering pada ternakruminansia kecil. Prosiding Pertemuan Ilmiah Ruminansia, 8-10 Nopember 2000, Cisarua, Bogor. 
Elvannudin, A. M. Tase, dan H, Hafid. 2016. Kajian pertumbuhan karkas dan bagian non karkas kambing lokal jantan pasca pemberian asam lemak terproteksi. Jurnal Ilmu Dan Teknologi Daging Peternakan Tropis. 3 (2): 1-9.

Ginting S.P., A. Tarigan, R. Hutasoit, D. Yulistiani. 2014. Referensi, kecernaan dan karakteristik fermentasi rumen beberapa spesies murbei pada kambing. JITV Vol. 19 (3) : $176-183$.

Hafid, H. 2005. Kajian pertumbuhan dan distribusi daging serta estimasi produktifitas karkas sapi hasil penggemukan. Disertasi Sekolah Pascasrjana, IPB. Bogor.

Hafid, H. 2011. Pengantar evaluasi karkas. Cetakan Pertama. Unhalu Press, Kendari.

Hafid, H., 2002. Pengaruh umur kronologis terhadap proporsi organ dalam ternak kambing. Majalah Ilmiah Agriplus. Fak. Pertanian Unhalu, Edisi No. 34 Tahun XII Mei 2002. Kendari.

Hafid, H., D. Agustina, N. S. Saminaya, dan R. Aka. 2014. Pemanfaatan sampah sayuran sampah dalam rangka peningkatan produktivitas kambing lokal (penerapan di wilayah pessisir sulawesi tenggara). Proseding seminar nasional memantapkan indonesia sebagai negara maritim yang tangguh. Universitas halu Oleo Kendari.

Hafid, H., Nuraini, dan A. Syam. 2003. Studi tentang karasteristik ternak kambing lokal yang berasal dari pola pemeliharaan tradisional. Jurnal Penelitian Mimbar Akademik. 18 (12): $111-117$.

Rianto, E., E Lindasari, E Purbowati. 2006. Growth and Carcass Physical Components of Thin Tail Rams Fed on Different Levels of Rice Bran. J.anim.Prod. 8 (1): 1411-2027
Suparman, H. Hafid, dan L. Baa. $2016^{\text {a }}$. Effect of natural feed mulberry and gliricidia against percentage non carcass and carcasses males goat ettawa cossbreed. Chalaza Jouenal Of Animal Husbandry. 1(2):53-57.

Suparman, H. Hafid, dan L. Baa. 2016 ${ }^{\text {. Kajian }}$ pertumbuhan dan produksi kambing peranakan etawa jantan yang diberi pakan berbeda. Jutnal Ilmu dan Teknologi Peternakan Tropis. 3 (3):19.

Widaningsih E. 2012. Performa kambing peranakan etawah muda dan produktivitas induk laktasi dengan sistem pemberian pakan yang berbeda di lahan pasca galian pasir. skripsi. Departemen Ilmu Produksi dan Teknologi Peternakan. Institut Pertanian Bogor. 